\title{
ICT POLICIES AS A MEANS TO INHIBIT SOCIAL EXCLUSION: The South African Case
}

\author{
Edgar A. Maldonado \\ Nicolai A. Pogrebnyakov \\ Annemijn F. van Gorp \\ Pennsylvania State University \\ University Park, PA U.S.A.
}

\begin{abstract}
Social exclusion is a multi dimensional phenomenon that manifests itself in the exclusion of an individual from one or more of the four following activities: production of goods and services, consumption, civil engagement, and social interaction. Information and communication technologies (ICTS) have been argued to have the potential to reduce these forms of social exclusion. However, the extent to which they deal with these different forms of social exclusion remains unknown. Therefore, in this study we examine how ICT policies in South Africa are being employed to reduce social exclusion. In particular, we analyze which dimensions of social exclusion are targeted in telecommunication laws and one of the ICT initiatives of the South African government, Multi-Purpose Community Centers (MPCCs). Using a framework that portrays the four forms of social exclusion within the discourses used in phenomenon debates (redistributionist, moral underclass, and social integrationist) for analysis, we find that ICT policies in South Africa address two of the four forms of social exclusion: production of goods and services and civil engagement, spanning both the redistributionist and social integrationist discourses of social exclusion.
\end{abstract}

Keywords Social exclusion, information and communication technologies, policy analysis, South Africa

\section{INTRODUCTION}

Social exclusion entails a multidimensional phenomenon that refers to the exclusion of individuals from full participation in society. It may manifest itself in a variety of

Please use the following format when citing this chapter:

Maldonado, E.A., Pogrebnyakov, N.A., and van Gorp, A.F., 2006, in IFIP International Federation for Information Processing, Volume 208, Social Inclusion: Societal and Organizational Implications for Information Systems, eds. Trauth, E., Howcroft, D., Butler, T., Fitzgerald, B., DeGross, J., (Boston: Springer), pp. 137-150. 
forms such as unemployment and lack of quality education. Increased ICT deployment and use are believed by many to have the potential of tackling a wide range of issues resulting from social exclusion such as unemployment, lack of political participation, and limited access to education, as ICTs provide a means for increased access to information and potential for knowledge sharing and learning (Katz and Rice 2002; Kennard 2001; Oden and Rock 2004; Oden and Strover 2002; Tufekcioglu 2003). For this reason, numerous governmental offices around the world have published policies aiming to increase ICT use. However, over the years it has also become clear that the information era in itself has generated and reinforced new forms of inequality and exclusion. A gap is rising between groups of people who can, and who cannot, get access to, and meaningfully use, ICTs. This has also been referred to as the digital divide (Zeitlyn et al. 1998).

Governments have introduced a variety of measures in an attempt to reduce this gap, and efforts have been taken to evaluate the impact of ICT policies. Nevertheless, the implicit conceptualizations of social exclusion in such policies, and hence the way ICT initiatives will inherently affect the digital divide and social exclusion, have not been analyzed thoroughly. Explicating conceptualizations of social exclusion allows insight into exactly which dimensions of social exclusion are targeted through social policies, and may shed light on which aspects need further attention to increase social inclusion.

South Africa constitutes an interesting case with regard to its attempts to increase social inclusion. In spite of being classified as an upper middle-income country, 'South Africa has one of the greatest income disparities and highest unemployment rates in the world. Reducing inequality and poverty in the post-apartheid environment has been one of the greatest challenges for the government of this country. The economy has grown rapidly since political changes in the 1990s, but unemployment still constituted 31 percent in $2003{ }^{2}$ While South Africa's telecommunication system is the best developed of the continent, counting more than 4 million fixed line subscribers and already 16 million mobile subscribers, Internet services still reach less than 3 million users that are concentrated in the urban centers of the country.

Hence, in this paper we analyze the extent to which South Africa addresses and handles social exclusion in ICT-related policy documents, and how a specific ICT initiative - the Multi-Purpose Community Centers initiative - deals with the social exclusion phenomenon. We will address the following questions: How do ICT policies address social exclusion in South Africa? How is this further reflected in governmental ICT projects?

The paper is structured as follows: First, we review conceptualizations of social exclusion and their relation to the digital divide. This is followed by a discussion of our methodology. Finally, the results of data analysis are presented and discussed.

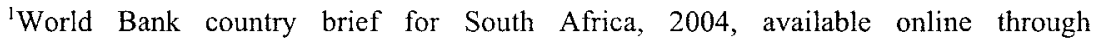
http://www.worldbank.org/.

${ }^{2}$ From the CIA's world factbook for South Africa, 2005; available at http://www.cia.gov/cia/ publications/factbook/geos/sf.html.
} 


\section{SOCIAL EXCLUSION AND THE DIGITAL DIVIDE}

Definitions of social exclusion are abundant. European Union documents define it as a process through which individuals or groups are wholly or partially excluded from full participation in the society in which they live (European Foundation for the Improvement of Living and Working Conditions 1995, p. 4). This definition highlights two aspects of the social exclusion phenomenon: it is a dynamic event and relates to a certain social context. Atkinson (1998) adds a third element, agency, affirming that "exclusion implies an act," thus indicating that a person is either excluded by the society or by his or her own will.

David (2003) discusses various circumstances that may lead to social exclusion: limited knowledge, lack of employment opportunities, low income levels, limited access to state and market services, limited geographical mobility, limited access to education, training and information, discrimination, limited family and community support, and resources. In addition, McDonagh (2006) explains that social exclusion is not only defined by poverty and deprivation, but is part of broader political and structural barriers to opportunities.

The concept of social exclusion used in this paper will be based in the definition of a socially excluded individual as used by Burchardt et al. (1999, p. 229):

An individual is socially exchuded if (a) he or she is geographically resident in a society, (b) he or she cannot participate in the normal activities of citizens in that society, and (c) he or she would like to so participate, but is prevented from doing so by factors beyond his or her control.

Normal activities are defined as five types of activity: consumption, generation of savings, production, political, and social (Burchardt et al. 1999).

\subsection{Digital Divide}

Social exclusion is interwoven in the phenomenon of the digital divide. The digital divide refers to the difference among those with access to information technologies and those without, and has been discussed at three different levels: the global divide, the social divide, and the democratic divide (Norris 2004). The global divide is related to the disparity of access between developed and developing countries. The social divide refers to the divergence of access among social groups in a nation. Finally, the democratic divide refers to the difference among those who use digital tools to engage in civic life and those who do not. The last two aspects are especially important in our discussion as they potentially constitute both cause and effect of social exclusion: both the social and democratic divide describe activities from which individuals are being excluded.

In a report for the European Community, Schienstock (1999) describes how the digital divide can actually lead to social exclusion. The author argues that a lack of technical skills drives people out of the job market, which is one of the first steps to become socially excluded. From this perspective, social exclusion is a consequence of 
the digital divide phenomenon. Nevertheless, the digital divide per se can be considered a form of social exclusion. In the words of a subject interviewed in Foley's article, whose job was not related to computers: "There is no huge benefit if you learn how to use computers and the Internet. However, if you don learn you are behind socially" (Foley 2004, p. 145). The interviewee did not see the computer as an empowerment tool, but understood that the lack of computer knowledge caused exclusion. Thus, in order to decrease the digital divide, we need to gain a better understanding of one of its basic underlying phenomena, social exclusion, and its many aspects, and bring together these formerly distinct research areas.

\subsection{Dimensions of Social Exclusion}

Whereas numerous studies have emphasized various aspects of social exclusion, the multidimensionality of the phenomenon has been widely accepted (Bradshaw 2003; Burchardt et al. 1999; Byrne 1999; Percy-Smith 2000; Saunders 2003). For example, Percy-Smith (2000) focused on the political dimension, the neighborhood dimension, the individual dimension, the spatial dimension, and the group dimension. Byrne (1999), citing Madanipour et al. (1998), suggested the following dimensions of the social exclusion phenomenon: political processes, access to employment, integration to the culture, and access to material resources. Although the last factor (access to material resources) could follow from the first three, this does not necessarily have to be the case. Burchardt et al. (1999) take a similar approach and identify five dimensions of social exclusion that are more related with the "normal activities" of a citizen: consumption activities, saving activities, production activities, political activities, and social activities. Finally, Bradshaw (2003) identifies four dimensions of exclusion: consumption, production, political engagement, and social interaction.

In this study we use Bradshaw's description as it integrates both Burchardt et al.'s and Byrne's representations of social exclusion, and additionally defines dimensions of social exclusion that could be addressed by means of ICT deployment. We redefine Bradshaw's third dimension, political engagement, to civil engagement so that it also includes activities where individuals are using governmental services. Table 1 describes the four dimensions.

\subsection{Theoretical Framework}

The previous section provided a conceptualization of social exclusion, structuring the phenomenon across four dimensions. However, since our goal is to analyze the extent to which South Africa addresses social exclusion in ICT-related policy documents, we need not only understand the manifestations of social exclusion as these dimensions address, but also on which causes of the phenomenon they concentrate.

With this goal in mind, we turn our attention to the academic literature that describes forces that lead an individual to become socially excluded. To this extent, Levitas (1999) categorization provides a comprehensive overview of forces that create social exclusion. Levitas finds that academic literature can be grouped into three major discourses, and lays out how these shape conceptualizations of social exclusion. Levitas 
Table 1. Dimensions of Social Exclusion

\begin{tabular}{|l|l|l|}
\hline \multicolumn{1}{|c|}{ Dimension } & \multicolumn{1}{|c|}{ Description } & \multicolumn{1}{c|}{ Manifestation } \\
\hline Consumption & $\begin{array}{l}\text { "The capacity to purchase goods } \\
\text { and services, as constrained by } \\
\text { low income relative to need"* }\end{array}$ & $\begin{array}{l}\text { Because of low income people } \\
\text { cannot access goods or } \\
\text { services }\end{array}$ \\
\hline Production & $\begin{array}{l}\text { "Lack of participation in } \\
\text { economically or socially valued } \\
\text { activities"* }\end{array}$ & $\begin{array}{l}\text { Unemployment; people are not } \\
\text { able to own businesses }\end{array}$ \\
\hline $\begin{array}{l}\text { Civil } \\
\text { engagement }\end{array}$ & $\begin{array}{l}\text { "Lack of involvement in local or } \\
\text { national decision making"* or } \\
\text { other activities related to being a } \\
\text { citizen }\end{array}$ & $\begin{array}{l}\text { The person does not participate } \\
\text { in the political process, or does } \\
\text { not have access to government } \\
\text { bureaucracy. }\end{array}$ \\
\hline $\begin{array}{l}\text { Social } \\
\text { interaction }\end{array}$ & $\begin{array}{l}\text { "Lacking emotional support or } \\
\text { integration with family, friends } \\
\text { or community"* }\end{array}$ & $\begin{array}{l}\text { Lack of integration with family } \\
\text { or community. }\end{array}$ \\
\hline
\end{tabular}

*Saunders 2003, p. 8

categorizes these discourses as redistributionist discourse (RED), moral underclass discourse (MUD), and social integrationist discourse (SID). RED is concerned with poverty and the social processes that cause it. MUD points out how the behavior of those in low-income neighborhoods causes and increases the gravity of their situation. SID perceives absence of paid employment as the principal cause of the social exclusion.

Combining RED, SID, and MUD with the four dimensions explained earlier, we built the conceptual framework showed in Figure 1. The four-dimensional framework will be used to identify the definitions of the phenomenon, which will facilitate the analysis of how policies handle the concept of social exclusion.

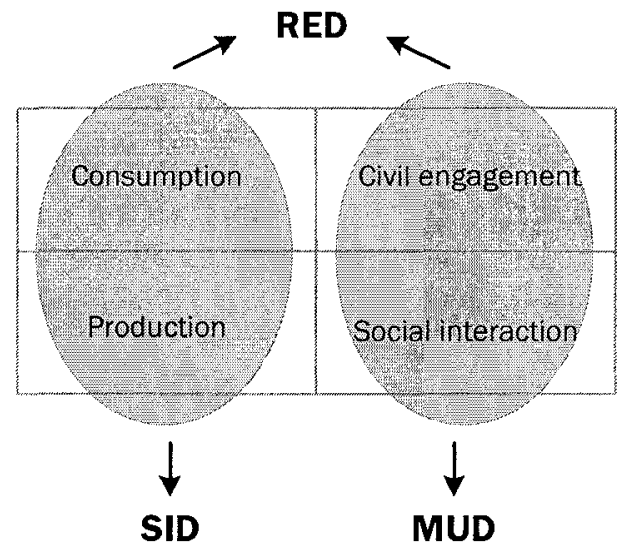

Figure 1. The Four-Dimensional Framework used in the Analysis of ICT Policies in South Africa 


\section{METHODOLOGY}

To answer our research questions, we first identify segments in South Africa's ICT policies that specifically address the concept of social exclusion, and conduct a policy analysis to unravel the conceptualizations of social exclusion. This is followed by an analysis of solutions that the policy offers to that particular problem. To this extent, we analyze one of the government's ICT implementation initiatives, namely the multipurpose community centers (MPCCs).

The reason for focusing on MPCCs is as follows. Our policy analysis began looking for notions of social exclusion in documents. After first examinations, we decided to narrow the scope of the study and focus on a specific initiative, which was included in the policies. The multipurpose community centers resulted in one that matched our criterion. Established under the auspices of the South African Universal Service Agency (USA), the MPCC initiative was designed as

the primary approach for the implementation of development communication and information as they can offer a wide range of services that communities can use for their own empowerment... Providing services and information in an integrated fashion seeks to address particular historical, social and economic factors, which characterized freedom of access to information and citizen participation in South Africa. ${ }^{3}$

This initiative looks to address elements that are related to social exclusion, so the framework could be applied.

Primary data sources for answering the first research question are publicly available government policy documents on the Internet. The definition of social exclusion given earlier was mapped on policy documents in order to search for relevant information in these documents. The study uses documents from three sources: (1) the Communications section of the official web site of the South African Government; (2) the Education section of the South Africa Government's web site; and (3) the web site of the MultiPurpose Community Centers (MPCC) of South Africa.

The initial set of documents selected for analysis can be divided into two categories: laws and reports regarding the MPCC initiative. The list of these documents is presented in Table 2.

A mix of theory-driven and open coding was used for data analysis, by interpretively reading the data. The concept of social exclusion as laid out above provided a first frame to analyze the documents, which led to the identification of the following high-level concepts that are involved in both ICT and social exclusion: (1) people, (2) government, and (3) technology. These three categories have subsequently been analyzed and iteratively expanded upon through open coding.

${ }^{3}$ From the MPCC Initiative web page, http://www.gcis.gov.za/mpcc/initiative/documents/ implementation/strategy.htm. 
Table 2. Documents Selected for Analysis

\begin{tabular}{|c|c|}
\hline Laws & MPCC Documents \\
\hline $\begin{array}{l}\text { Electronic Communications and } \\
\text { Transactions Act, } 2002 \text { (Presidency of } \\
\text { the Republic of South Africa, } \\
\text { http://www.internet.org.za/ect_act.html } \\
\text { \#Objects of Act) }\end{array}$ & $\begin{array}{l}\text { MPCC Business Plan (http:// } \\
\text { www.gcis.gov.za/docs/publications/ } \\
\text { mppcplan.htm) }\end{array}$ \\
\hline $\begin{array}{l}\text { Telecommunications Amendment Act, } \\
2001 .\end{array}$ & $\begin{array}{l}\text { Communication Strategy for Govern- } \\
\text { ment's Multi Purpose Community Center } \\
\text { initiative (http://www.gcis.gov.za/mpce/ } \\
\text { initiative/documents/implementation/ } \\
\text { strategy.htm) }\end{array}$ \\
\hline \multirow{4}{*}{$\begin{array}{l}\text { Telecommunications Act, } 1996 \text { (Presi- } \\
\text { dency of the Republic of South Africa, } \\
\text { http://www.polity.org.za/html/govdocs/ } \\
\text { legislation/1996/act96-103.html) }\end{array}$} & $\begin{array}{l}\text { Draft } 2 \text { of the Guideline document on the } \\
\text { MPCC Project. }\end{array}$ \\
\hline & $\begin{array}{l}\text { Correlation of ISRDS nodes and MPCCs } \\
\text { (http://www.gcis.gov.za/mpcc/initiative/ } \\
\text { documents/implementation/correlation. } \\
\text { htm) }\end{array}$ \\
\hline & $\begin{array}{l}\text { Report on the establishment of Govern- } \\
\text { ment Multi-Purpose Community Centers: } \\
\text { Towards an integrated information and } \\
\text { service delivery system, by Chief } \\
\text { Directorate: Provincial and Local Liaison } \\
\text { (http://www.gcis.gov.za/mpcc/initiative/ } \\
\text { documents/implementation/report.htm) }\end{array}$ \\
\hline & $\begin{array}{l}\text { Report: Multi Purpose Community } \\
\text { Centers/One stop shops as vehicles of a } \\
\text { shared service delivery approach } \\
\text { (http://www.gcis.gov.za/mpcc/initiative/ } \\
\text { documents/implementation/ } \\
\text { servicedelivery.htm) }\end{array}$ \\
\hline
\end{tabular}

\section{RESULTS}

\subsection{South Africa's Telecommunications Laws}

Policy documents acknowledge the existence of historically disadvantaged groups and encourage ownership and control of telecommunication services by persons from these groups. However, the Telecommunications $\mathrm{Act}^{4}$ contains only general provisions related to historically disadvantaged groups (e.g., "due regard shall be given to appli-

${ }^{4}$ Telecommunications Act, 1996, http://www.polity.org.za/html/govdocs/legislation/ 1996/act96-103.html. 
cations by persons from historically disadvantaged groups" (section 35(3)). The Telecommunications Act does not provide any specific incentives for these groups to become owners of, and gain control over, telecommunication services. However, the laws do provide specific guidelines on what should be done to promote services to areas where such groups live. The Telecommunications Act with the Amendment (2001) establishes the Universal Service Agency (USA) (sections 58 through 64) that promotes universal access to ICT in under served areas. The USA is funded from the state budget and conducts tenders to purchase equipment in order to provide telecommunications services to underserviced areas. In addition, the USA stimulates public awareness of the benefits of telecommunication services. The USA aims at targeting the production and civil engagement dimensions of social exclusion. The production dimension is targeted by establishing computer laboratories in schools and providing them with ICT equipment. Students that have access to such laboratories will have a certain number of computer skills, which will make them more competitive on the job market. By providing equipment and connectivity for e-government services, the Agency targets the civil engagement dimension of social exclusion.

In addition to the USA, the Telecommunications Act established the Universal Service Fund (sections 65 through 68 ) that is used for subsidizing certain population groups in order to engage them in adoption of technology. Money for the Fund is provided by holders of licenses for telecommunication services (such as cellular operators). The Telecommunications Regulatory Authority determines the categories of persons it provides with assistance from the Fund. Money provided to these persons would be used toward compensating the cost of provision of telecommunication services to them.

However, the Telecommunications Act and the Amendment are targeted at "generic" use of telecommunication services (i.e., they do not specify or imply reasons from any of the four dimensions listed in Table 1 on what issues the adoption of a telecommunication service or technology will resolve). It is through institutions that are established through the policy, including the Universal Service Agency and the Universal Service Fund, that social exclusion on a large scale can be tackled.

The USA created in accordance with provisions of the Telecommunications Act (Chapter VII) has established a network of so-called telecenters across South Africa with the goal of providing access to ICTs to areas with limited or no level of telecommunications access (Telecenter Project Directory 2003 $3^{5}$ ). This purpose is achieved in telecenters by providing access to various equipment (e.g., computers, video equipment, etc.) as well as to ICT training services. There are several categories of telecenters, which differ in their purposes (for example, providing IT services in underserviced areas, in schools, etc.). One of these categories is telecenters at MPCCs, which allow, as will be discussed below, use of ICT resources provided by telecenters to facilitate and complement government services provided at MPCCs. However, MPCCs do not just serve as a source for information from the government or a means for citizens to communicate with the government. They also allow people that otherwise do not have access to ICT resources to use those available at the centers. For example,

\footnotetext{
${ }^{5}$ http://www.usa.org.za/TELECENTER\%20PROJECT\%20DIRECTORY.doc
} 
using these resources allows people to find a job or start their own business. This combination of available information and means for practical application of this information allows MPCCs to promote social inclusion from several perspectives simultaneously, which in turn was the reason for targeting MPCCs in this research.

\subsection{Multi-Purpose Community Centers (MPCCs)}

The Multi-Purpose Community Center is an initiative that the government of South Africa is pushing to deliver services and information about government resources to remote communities. The Government Communication and Information System (GCIS) works with local governmental offices and the private sector to coordinate the development and management of these centers.

This idea was officially introduced in 1999 in the Cabinet Memorandum 15, dated November 18, 1999. Since the creation of these "one stop" centers, the GCIS has focused its goals on delivery of not only technology, but also services and resources that this tool can provide to communities. Figure 2 shows how GCIS delivers ICT services to communities and thus plays a key role in the development of communities.

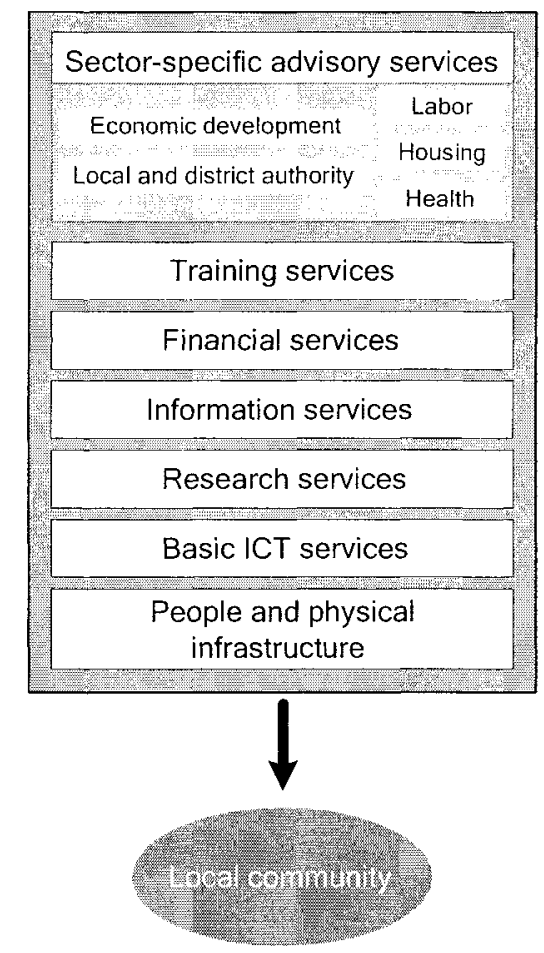

Figure 2. Layered Structure of Information and Service Delivery (adapted from Diagram 3.2of "The MPCC Business Plan," p. 13 [http://www.gcis.gov.za/mpcc/ initiative/documents/ implementation/businessplan.pdf]) 
The graphic in Figure 2 can be compared with the open system interconnection model (OSI model) in communications. Every layer can operate independently of the other layers but it is necessary for all layers to effectively communicate. In line with this model, the GCIS acknowledges that technology is an important component in the process of development, but it is not sufficient to guarantee it; information, financial and training activities must be offered to allow technology to contribute in an effective way.

The MPCC business plan states that its initiative aims at tackling historical, social, and economic problems of the South Africa population. This document lists some of those problems:

poverty, high unemployment, low standards of living (people living below the poverty line), poor access to basic services, remote settlement patterns, lack to access to technology and information, poor health services, insufficient education and skills, poor infrastructure, etc. ${ }^{6}$

Kapur recommends that developing countries should identify the major constraints in themselves and examine if new technologies can solve these in a fundamental way (2001, p.14), instead of copying models and technologies of the world leaders. That is the case with the MPCC model. There is no reference to any other model or similar development in another country in the entire MPCC business plan document; all ideas expressed in the manuscript come from specific South Africa issues and locally generated solutions.

GCIS regards MPCCs as a tool to focus on socio-economical problems, which goes further than just solving the digital divide issue. In the MPCC Business Plan, the institution acknowledges that providing ICT to communities can be beneficial only if they address real, everyday problems in the communities. An MPCC is a resource that can help to improve the standard of life, but it must be directed to include the citizen in the process:

An MPCC aims to empower the poor and disadvantaged by means of access to information, services and resources from governmental and nongovernmental source, which can be used for their own development. ${ }^{7}$

The MPCC business plan document gives specific examples of how MPCCs try to accomplish this. The manuscript describes four scenarios where four potential clients use the center to carry out different tasks: a community member, a job seeker, a community organization, and an entrepreneur.

The community member is a woman looking for information (government regulations, medical care, school projects, etc.) to improve an informal cr he in her community. The job seeker is a man using MPCC facilities to create a CV to apply for a job; since he does not have a phone number, MPCC phone and fax numbers are provided as

${ }^{6} \mathrm{MPCC}$ Business Plan, Chapter 4, page 14 (http://www.gcis.gov.za/docs/publications/ mpccplan/chap4.pdf).

${ }^{7}$ MPCC Business Plan, Executive Summary, page 3 (http://www.gcis.gov.za/docs/ publications/mpecplan/summary.pdf) 
contact information. The community organization is a woman who wants to look for information on governmental initiatives for training community women in sewing and knitting; she obtains this information and brings it to an informal women's organization. The entrepreneur is a worker in the building industry who knows that the offer of bricks in his town is low, and the nearest place to buy them is 30 miles away; he wants to look for guidelines to start a business for manufacturing bricks locally.

These initiatives can be mapped on two out of the four dimensions of social exclusion explained in the data analysis section: production and civil engagement. Lowering unemployment and connecting people with the government are the principal goals that underlie the implementation of the MPCCs. The other two forms of social exclusion are not addressed. MPCC documentation does not propose solutions that stimulate social interaction or consumption. Figure 3 shows the MPCC initiative in the framework exposed in the first part of this document.

In a mental exercise, it is possible to extrapolate the consequences of bringing telecommunication technologies to rural activities. It is possible that the simple act of providing access can stimulate interaction between distant relatives, friends, or communities. But the MPCC policies do not provide direct activities to promote this interaction. The problem of the diversity of languages-South Africa has 11 official languages---for example, is not taken into account.

The same happens with the possibilities of using ICT for purchases or other forms of consumption. These centers could be a vehicle for the distribution of goods that are not available locally in some communities. The documents seem to avoid any association of the centers with commerce or other form of e-business.

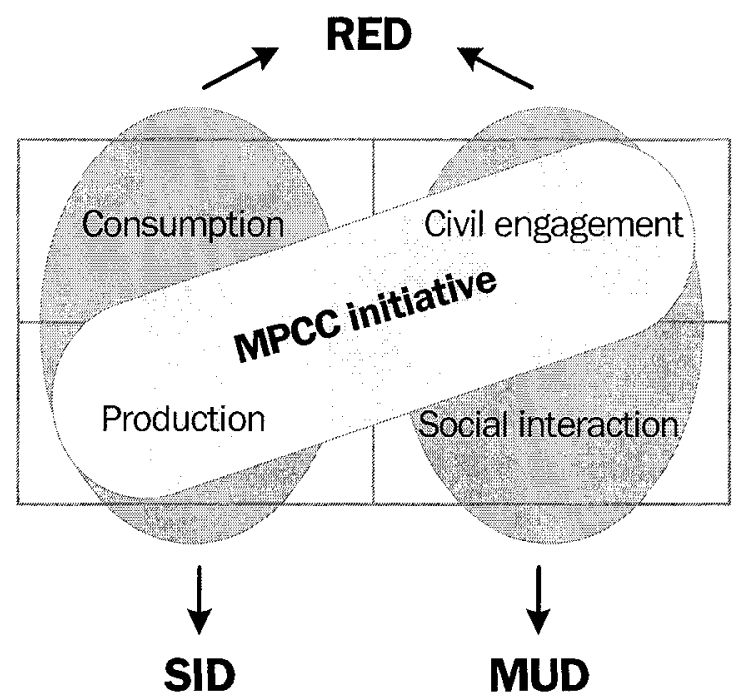

Figure 3. The MPCC Initiative Mapped to the Four Dimensional Framework 
Although the GCIS has carefully planned the launch and management of the MPCC (advertisement, costs, and implementation planning), the MPCC business plan document acknowledges the problems that the implementation could face: (1) since the initiative is an effort shared with the private sector, the lack of incentives to the stakeholders can drop their participation and interest; (2) some areas do not have the minimal services required (electricity and water); and (3) the distributed character of the program makes it hard to control.

\section{CONCLUSION}

Social exclusion is an acute problem for South Africa as the country is recovering from the consequences of apartheid, which had a profound effect on the country's economic and social condition. Information and communication technologies provide a way of tackling some forms of exclusion. This study developed a four-dimensional framework to identify how specific ICT-related actions promoted by South African laws and government initiatives can be considered as social exclusion palliatives.

This paper contributes to research on the digital divide by looking at how social exclusion - a basic phenomenon underlying the digital divide--is addressed through adoption and implementation of ICT policies. We decomposed social exclusion into several dimensions and connected these dimensions with factors that caused them. We found that policy documents do not contain provisions that specifically address reduction of social exclusion. This task is reserved to institutions that have been established as envisioned by these policies. The governmental initiative of MPCCs targets the civil engagement and production dimensions of social exclusion, as can be observed in the MPCC's business plan, which specifically states the objective to reduce unemployment, insufficient access to government services, and lack of education and skills.

These dimensions span two social exclusion discourses: the redistributionist discourse (RED) and the social integrationist discourse (SID). The MUD discourse does not have a place in the MPCC initiative. This result was expected since MUD assumes that the individual, not external factors, is the cause of social exclusion.

Because social exclusion is a multidimensional phenomenon and includes consumption, production, civil engagement, and social interaction dimensions, policy responses should ideally take into account this multidimensionality. While spreading efforts to reduce the different dimensions of social exclusion over different policies and initiatives is a means to take an overall comprehensive approach to inhibiting social exclusion, we recommend the use of this four-dimensional framework in policy generation processes to allow for a more integrative handling of the four dimensions in order to inhibit social exclusion. First, explicating how to deal with all dimensions likely increases the attention paid specifically to inhibiting social exclusion. As we showed, South Africa's policies do not specifically address social exclusion, but nevertheless this constitutes an important issue, taking into account South Africa's large gap between poor and rich. Second, the spread of efforts to reduce social exclusion over different initiatives, all dealing with different dimensions could result in overlap of resources. The spread of efforts requires significant coordination by different agencies in order to align their efforts, and thus is prone to failure. 
In addition, we call for greater attention to the phenomenon of social exclusion itself by academics who research the digital divide. This paper, drawing on relevant literature, showed that causes of social exclusion are different depending on the dimension of the latter. As the concepts of digital divide and social exclusion are highly interwoven, specifically addressing the multiple dimensions of social exclusion and how they are both a cause and consequence of the digital divide is of prime importance. More insight on how these dimensions are addressed in policies and ICT projects will provide a way forward to further reduce the global, social, and democratic divide.

\section{References}

Atkinson, A. B. "Social Exclusion, Poverty and Unemployment," in A. B. Atkinson and J. Hills (eds.), Exclusion, Employment and Opportunity, CASE Paper 4, London: Center for the Analysis of Social exclusion, London School of Economics, 1998.

Bradshaw, J. "How Has the Notion of Social Exclusion Developed in the European Discourse?," paper presented at the Plenary Session, 2003 Australian Social Policy Conference, University of New South Wales, 2003.

Burchardt, T., Le Grand, J., and Piachaud, D. "Social Exclusion in Britain 1991-1995," Social Policy and Administration (33:3), 1999, pp. 227-244.

Byrne, D. S. Social Exclusion, Philadelphia: Open University Press, 1999.

David, M. "The Politics of Communications: Information Technology, Local Knowledge and Social Exclusion," Telematics and Informatics (20), 2003, pp. 235-253.

European Foundation for the Improvement of Living and Working Conditions. Public Welfare Services and Social Exclusion: The Development of Consumer Oriented Initiatives in the European Union, Dublin: The Foundation, 1995.

Foley, P. "Does the Internet Help to Overcome Social Exclusion," Electronic Journal of eGovernment (2:2), 2004, pp. 139-146.

Kapur, S. "Developing Countries in the Network Economy: A Blueprint for Success," paper presented at the International Symposium on Network Economy and Economic Governance, Beijing, China, April 19-20, 2001.

Katz, J., and Rice, R. Social Consequences of Internet Use, Cambridge, MA: The MIT Press, 2002.

Kennard, W. "Equality in the Information Age," in B. Compaine (ed.), The Digital Divide: Facing a Crisis or Creating a Myth, Cambridge, MA: The MIT Press, 2001.

Levitas, R. "New Labour and Social Exclusion," paper presented at the Political Studies Association Conference, Nottingham, England, 1999.

Madanipour, A., Cars, G., and Allen, J. Social Exclusion in European Cities, London: Jessica Kingsley, 1998.

McDonagh, J. "Transport Policy Instruments and Transport-Related Social Exclusion in Rural Republic of Ireland," Journal of Transport Geography, 2006 (forthcoming; available online August 11, 2005).

Norris, P. "The Digital Divide," in F. Webster (ed.), The Information Society Reader, New York: Routledge, 2004, pp. 273-286.

Oden, M., and Rock, C. "Beyond the Digital Access Divide, Developing Meaningful Measures of Information and Communications Technology Gaps,"paperpresented at the Fifth Internet Research Conference: Ubiquity?, University of Sussex, UK, September 19-22, 2004.

Oden, M., and Strover, S. "Links to the Future: Information and Telecommunications Technology and Economic Development in the Appalachian Region," report presented to the Appalachian Regional Commission, Washington, DC, 2002. 
Percy-Smith, J. "Introduction: The Contours of Social Exclusion," in J. Percy-Smith (ed.), Policy Responses to Social Exclusion: Towards Inclusion?, Philadelphia: Open University Press, 2000, pp. 2-22.

Saunders, P. "Can Social Exclusion Provide a New Framewrok for Measuring Poverty?," paper presented at the Measuring Social Inclusion and Exclusion: Dilemmas and Directions, University of Queensland, Australia, July 25, 2003.

Schienstock, G. "Social Exclusion in the Learning Economy," paper presented at the European Socio-Economic Research Conference, Brussels, April 28-30, 1999.

Tufekcioglu, Z. In Search of Lost Jobs: The Rhetoric and Practice of Computer Skills Training, unpublished doctoral dissertation, University of Texas, Austin, Texas. 2003.

Zeitlyn, D., Bex, J., and David, M. "Access Denied: The Politics of New Communications Media," Telematics and Informatics (15), 1998, pp. 219-230.

\section{About the Authors}

Edgar Maldonado is a Ph.D. candidate in the College of Information Sciences and Technology at the Pennsylvania State University. He has an undergraduate degree in Electronic Engineering from Simon Bolivar University in Caracas, Venezuela. Before entering graduate school, Edgar worked as a software support engineer for banking networks, with projects in Venezuela, Trinidad and Tobago, Panama, Guatemala, and Cayman Islands. Edgar's research interests include education policies and their influence in the development of knowledge based societies and economies, and learning theories for information technologies. Edgar can be reached at eam264@psu.edu.

Nicolai Pogrebnyakov is a Ph.D. candidate in the College of Information Sciences and Technology at the Pennsylvania State University. Nicolai holds an undergraduate degree in Informatics from the Belarussian State University for Informatics and Radioelectronics in Minsk, Belarus. Before entering graduate school, he was a software developer. His research interests include the use of information and communication technologies for coordination among relief organizations and mechanisms for acquisition of new technologies by developing countries. Nicolai can be reached at nap151@psu.edu.

Annemijn van Gorp is a Ph.D. candidate in the College of Information Sciences and Technology at the Pennsylvania State University. She has an M.Sc. degree in Systems Engineering, Policy Analysis, and Management from Delft University of Technology in the Netherlands. Annemijn's research interests include the changing roles of national, regional, and international institutions in the provision of telecommunications services, and the effect of policies, market structure, and firm strategies on the provision of advanced communication and Internet access services. Annemijn can be reached at avangorp@ist.psu.edu. 